GEOLOGICAL SURVEY OF DENMARK AND GREENLAND BULLETIN $3 \cdot 2004$

\title{
Late Quaternary environmental changes recorded in the Danish marine molluscan faunas
}

Kaj Strand Petersen

GEOLOGICAL SURVEY OF DENMARK AND GREENLAND MINISTRY OF THE ENVIRONMENT 


\section{Geological Survey of Denmark and Greenland Bulletin 3}

\section{Keywords}

Bottom-communities, climate changes, Danish, environment, interglacial-glacial cycle, Late Quaternary, marine, mollusc faunas.

\section{Cover}

Donax vittatus on the sandy shores of northern France.

\section{Kaj Strand Peteresen}

Danmarks og Grønlands Geologiske Undersøgelse

Øster Voldgade 10, DK-1350 Copenhagen K, Denmark

E-mail: ksp@geus.dk

Scientific editor of this volume: Svend Stouge

Editorial secretaries: Esben W. Glendal and Birgit Eriksen

Referees: Svend Funder and Gotfred Høpner Petersen, Denmark

Illustrations: Gurli E. Hansen Bengaard and Henrik Klinge Pedersen

Digital photographic work: Benny M. Schark and Jakob Lautrup

Graphic production: Knud Gr@phic Consult, Odense, Denmark

Printers: Schultz Grafisk, Albertslund, Denmark

Manuscript submitted: 9 January 1998

Final version approved: 11 December 2003

Printed: 15 July 2004

ISBN 87-7871-122-1

\section{Geological Survey of Denmark and Greenland Bulletin}

The series Geological Survey of Denmark and Greenland Bulletin replaces Geology of Denmark Survey Bulletin and Geology of Greenland Survey Bulletin.

\section{Citation of the name of this series}

It is recommended that the name of this series is cited in full, viz. Geological Survey of Denmark and Greenland Bulletin. If abbreviation of this volume is necessary, the following form is suggested: Geol. Surv. Den. Green. Bull. 3, 268 pp.

\section{Available from}

Geological Survey of Denmark and Greenland Øster Voldgade 10, DK-1350 Copenhagen K, Denmark

Phone: +45381420 00, fax: +45381420 50, e-mail: geus@geus.dk

or

Geografforlaget Aps

Rugårdsvej 55, DK-5000 Odense C, Denmark

Phone: +45634416 83, fax: +4563441697, e-mail: go@geografforlaget.dk

\section{(c) Danmarks og Grønlands Geologiske Undersøgelse (GEUS), 2004}




\section{Contents}

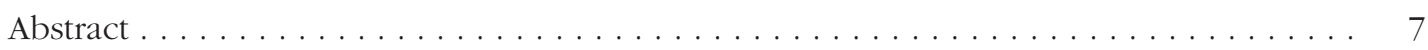

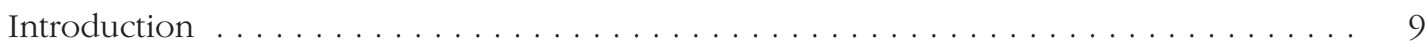

Danish sites with marine sediments ......................... 9

The Late Pleistocene . . . . . . . . . . . . . . . . . . . . . . . . . 10

The Holocene . . . . . . . . . . . . . . . . . . . . . . . . . . . . . . . . 12

The recent fauna of shell-bearing molluscs compared to the subfossil fauna . . . . . . . . 12

Molluscan finds within the seven regions during the Holocene . . . . . . . . . . . . . . 15

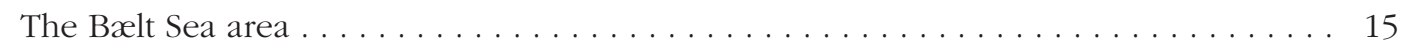

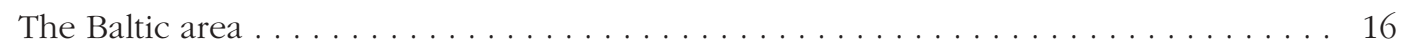

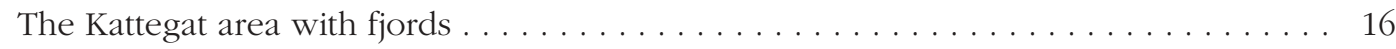

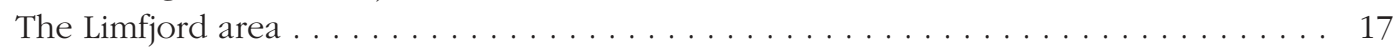

The North Sea . . . . . . . . . . . . . . . . . . . . . . . . . . . . . . . . . . . . 19

The Vendsyssel area . . . . . . . . . . . . . . . . . . . . . . . . . . . 20

The Skagen Well area . . . . . . . . . . . . . . . . . . . . . . 22

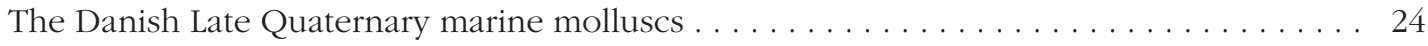

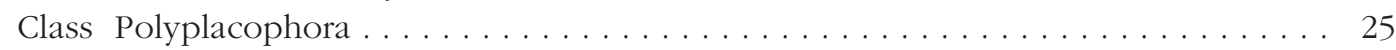

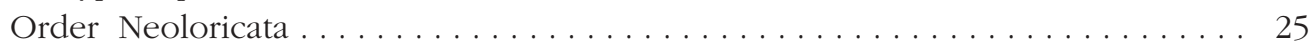

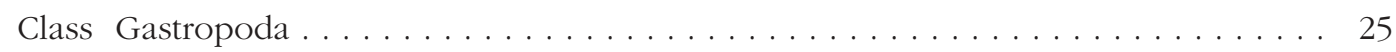

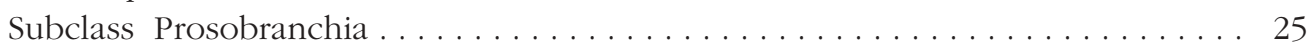

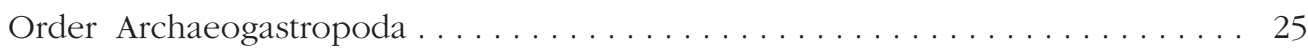

Order Mesogastropoda .............................. 28

Order Heterogastropoda . . . . . . . . . . . . . . . . . . . . . . . . . . . . . 39

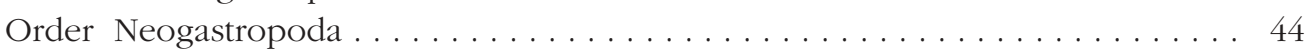

Subclass Heterobranchia ........................... 50

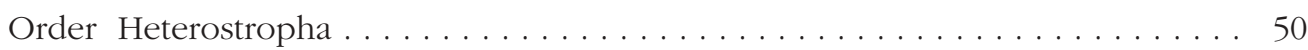

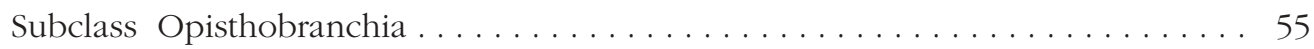

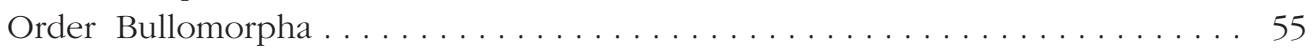

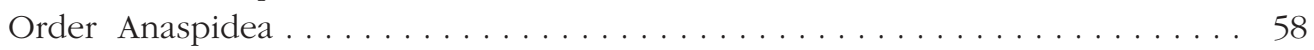

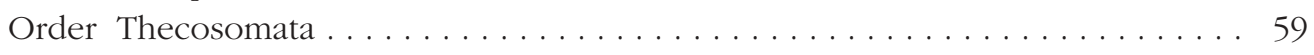

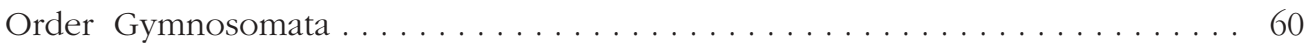

Subclass Pulmonata ............................. 60

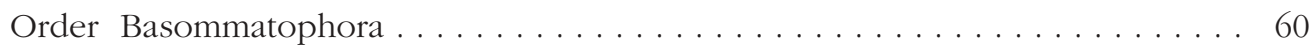

Class Scaphopoda ................................. 60

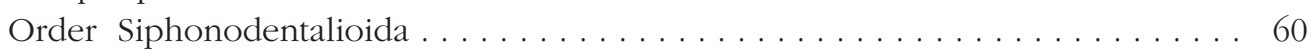

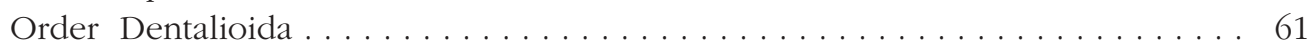

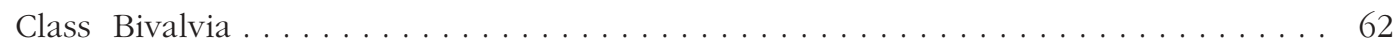

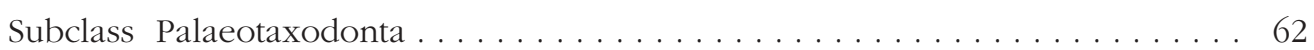

Order Nuculoida . . . . . . . . . . . . . . . . . . . . . . . . . 62

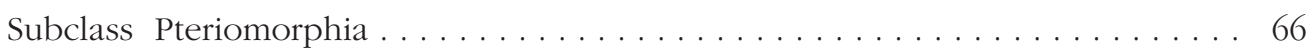

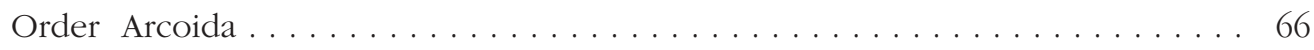

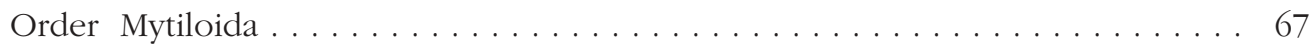

Order Pteroida ................................ 69

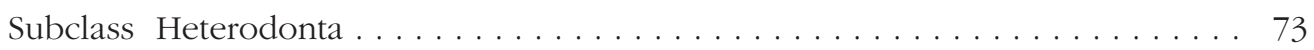

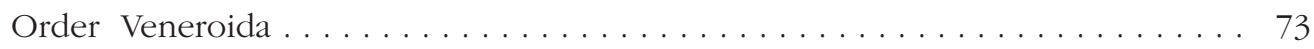

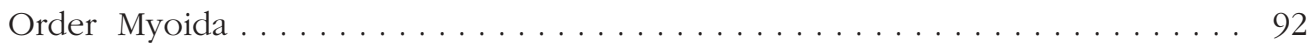

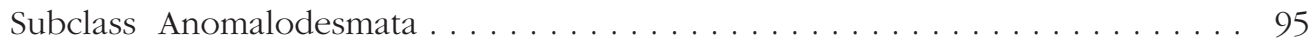

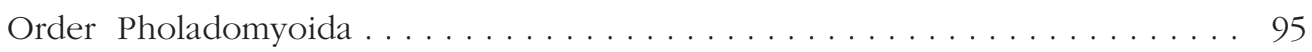


The Skagen Well . . . . . . . . . . . . . . . . . . . . . . . . . 98

The Skagen Well - perspectives . . . . . . . . . . . . . . . . . . . . . . . 98

The pre-Late Quaternary deposits . . . . . . . . . . . . . . . . . . . . . . . . . . . 99

The Late Pleistocene . . . . . . . . . . . . . . . . . . . . . . . . . . . . . . . . 99

Eemian deposits . . . . . . . . . . . . . . . . . . . . . . . . . 99

The Early/Middle Weichselian, marine and glacigene deposits . . . . . . . . . . . . . 100

The Late Weichselian marine and glacigene deposits . . . . . . . . . . . . . . . . . 101

The Holocene . . . . . . . . . . . . . . . . . . . . . . . . . . . . . . . . . . . . 102

The Preboreal-Boreal $10000-8000{ }^{14} \mathrm{C}$ years B.P. . . . . . . . . . . . . . 103

The Atlantic $8000-5000{ }^{14} \mathrm{C}$ years B.P. . . . . . . . . . . . . . . . . . . 104

The Subboreal $5000-2500{ }^{14} \mathrm{C}$ years B.P. . . . . . . . . . . . . . . . . . . 105

The Subatlantic $2500-{ }^{14} \mathrm{C}$ years B.P. . . . . . . . . . . . . . . . . . . . . 105

The older Subatlantic . . . . . . . . . . . . . . . . . . . . . . . . . 106

The younger Subatlantic . . . . . . . . . . . . . . . . . . . . . . . 107

Conclusive remarks on the Skagen Well . . . . . . . . . . . . . . . . . 112

The environmental changes through time in the seven sectors based on the

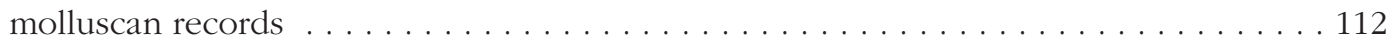

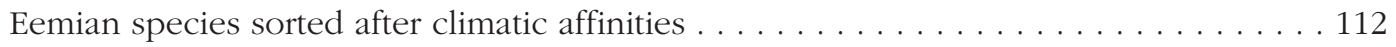

The Bælt Sea . . . . . . . . . . . . . . . . . . . . . . . . . . . . . 112

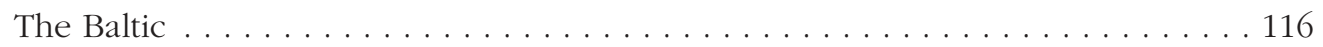

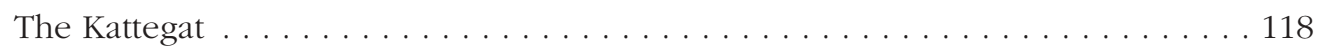

The North Sea . . . . . . . . . . . . . . . . . . . . . . . . . 120

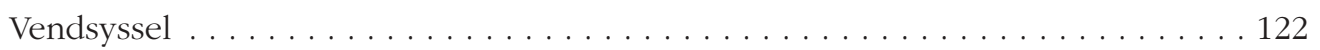

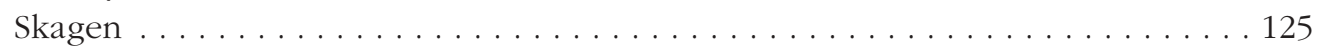

Early/Middle Weichselian species sorted after climatic affinities . . . . . . . . . . 126

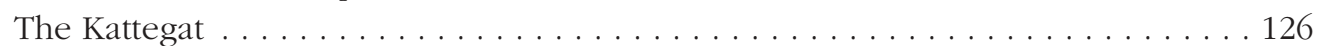

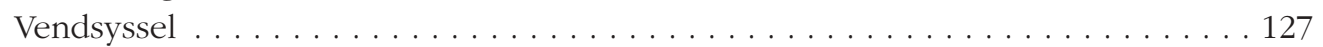

Skagen . . . . . . . . . . . . . . . . . . . . . . . . . . . . . . . . . . . 129

Late Weichselian species sorted after climatic affinities . . . . . . . . . . . . . . 130

Vendsyssel . . . . . . . . . . . . . . . . . . . . . . . . . . . 130

Skagen ..................................... 132

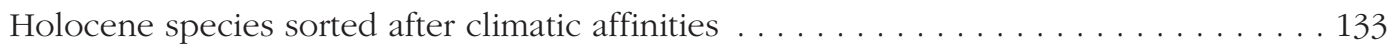

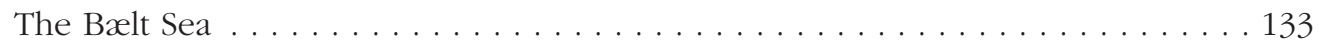

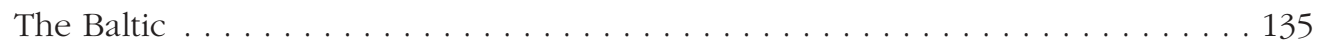

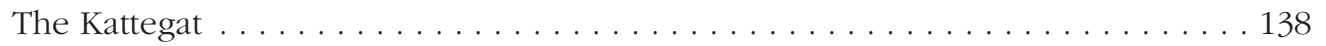

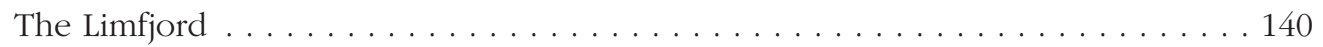

The North Sea . . . . . . . . . . . . . . . . . . . . . . . 143

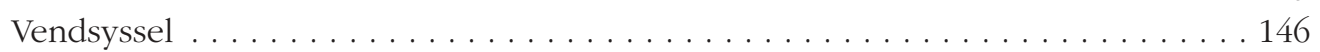

Skagen . . . . . . . . . . . . . . . . . . . . . . . . . . . . . . 149

The environmental changes within the seven regions through the Late Quaternary

evaluated by the molluscan communities met with in the seven stages . . . . . . . . 151

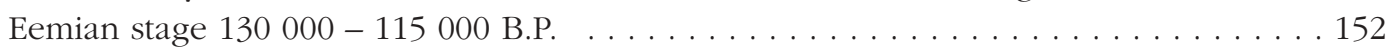

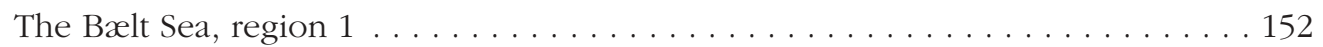

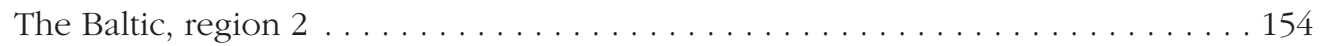

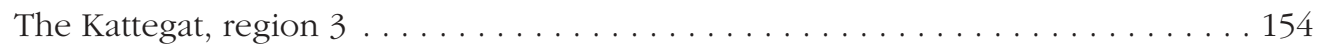

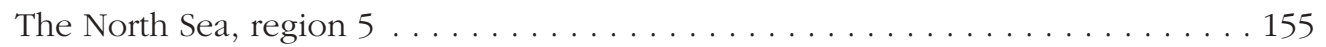

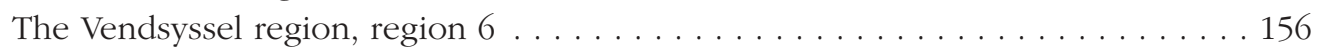

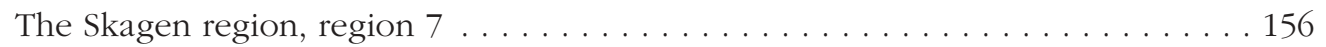

Early/Middle Weichselian stage $115000-25000$ B.P. . . . . . . . . . . . . . . . . 157

The Kattegat, region $3 \ldots \ldots \ldots \ldots \ldots \ldots \ldots \ldots \ldots \ldots$

The Vendsyssel region, region $6 \ldots \ldots \ldots \ldots \ldots \ldots$ 


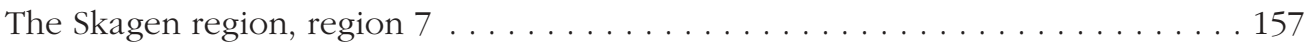

Late Weichselian stage $25000-10000$ B.P. . . . . . . . . . . . . . . . . . 158

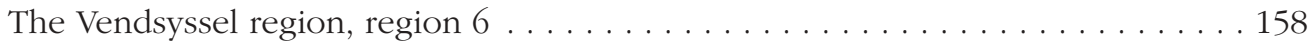

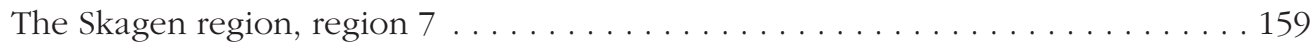

The Preboreal-Boreal stage $10000-8000{ }^{14} \mathrm{C}$ years B.P. . . . . . . . . . . . . . . . 159

The North Sea, region $5 \ldots \ldots \ldots \ldots$. . . . . . . . . . . . . . . . . . . . . . . . . . . . . . . . . . . . . . . . . . . . . . .

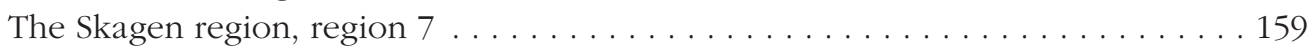

The Atlantic stage $8000-5000{ }^{14} \mathrm{C}$ years B.P. . . . . . . . . . . . . . . . . . . . . 160

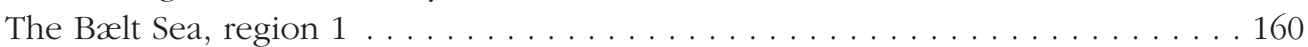

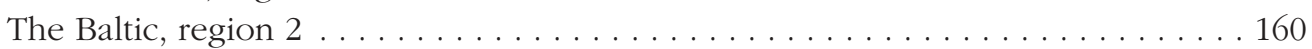

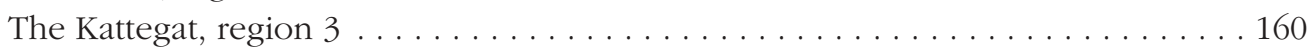

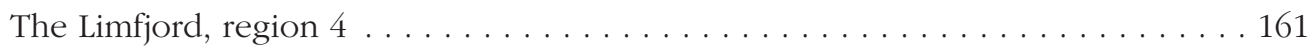

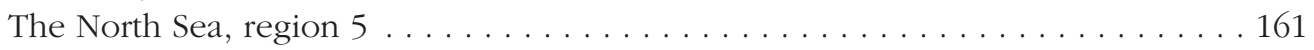

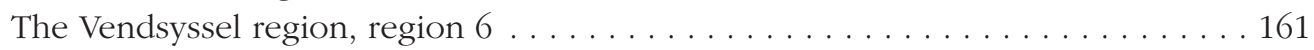

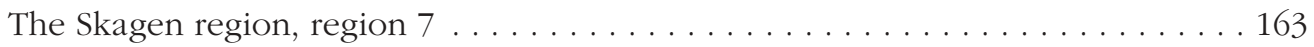

The Subboreal stage $5000-2500{ }^{14} \mathrm{C}$ years B.P. . . . . . . . . . . . . . . . . . 163

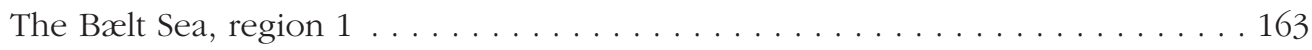

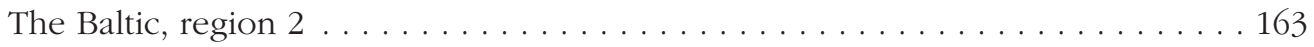

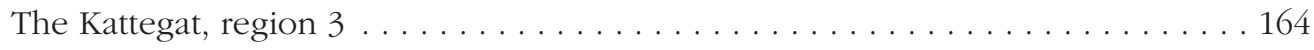

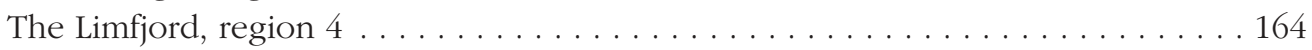

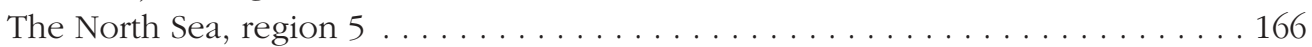

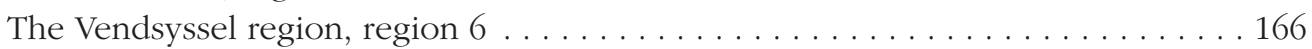

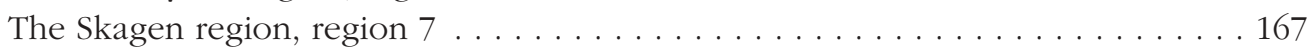

The Subatlantic stage $2500-{ }^{14} \mathrm{C}$ years B.P. . . . . . . . . . . . . . . . . . . . . 167

The Bælt Sea, region $1 \ldots \ldots \ldots \ldots \ldots \ldots$

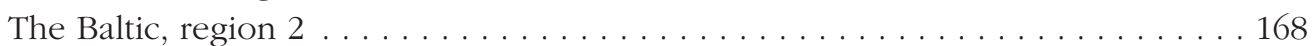

The Kattegat, region $3 \ldots \ldots \ldots \ldots \ldots \ldots \ldots$

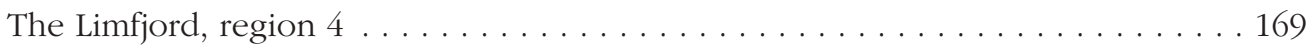

The North Sea, region 5 . . . . . . . . . . . . . . . . . . . . . . . . . . . . . . 169

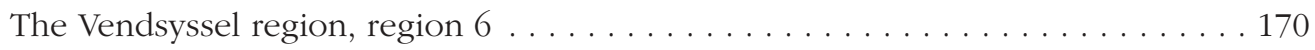

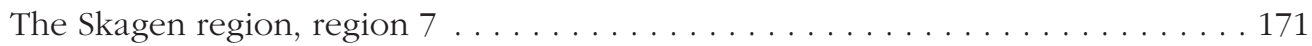

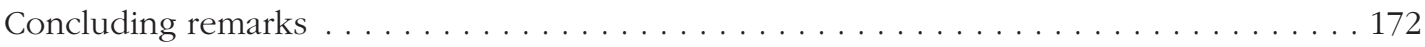

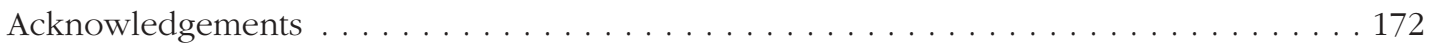

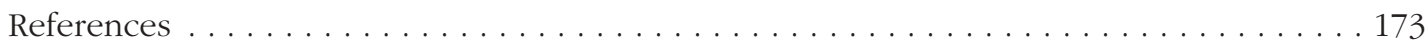

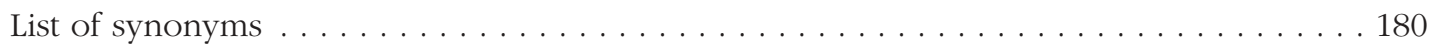

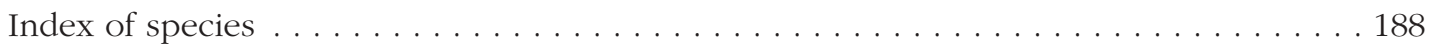

Appendix $1 \ldots \ldots \ldots \ldots$. . . . . . . . . . . . . . . . . . . . . . . . . 197

Recent species . . . . . . . . . . . . . . . . . . . . . . . . . . . . . . . . . . . . . . . 197

Subfossil species . . . . . . . . . . . . . . . . . . . . . . . . . . . . . . 201

Recent species sorted after climatic affinities . . . . . . . . . . . . . . . . . . . . 204

Subfossil species sorted after climatic affinities . . . . . . . . . . . . . . . . . . . 208

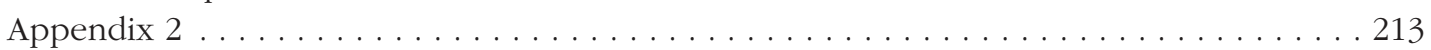

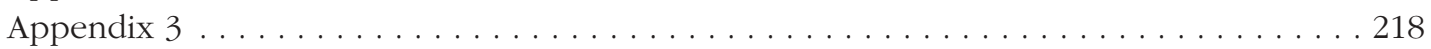

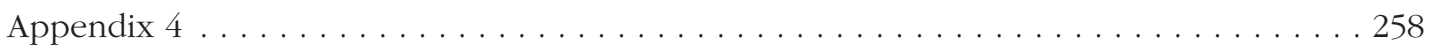

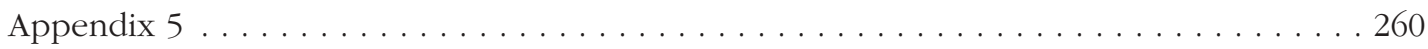

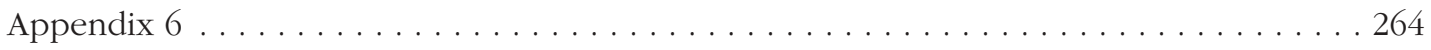


28-06-2004, 08:45 
Petersen, K.S. 2004: Late Quaternary environmental changes recorded in the Danish marine molluscan faunas. Geological Survey of Denmark and Greenland Bulletin 3, 268 pp.

Late Quaternary, marine deposits in Denmark have yielded 247 subfossil species of molluscs. The sites are presented, and comparisons are made between the subfossil mollusc assemblages and the 278 shell-bearing mollusc species presently living in the Danish seas. 184 species are common to the two groups. The 63 species no longer occurring around Denmark are used as indicators of changing environmental conditions, including temperature, salinity and depth, throughout the last 130000 years. Seven modern faunal regional units are defined and considered: the Bælt, the Baltic, the Kattegat, the Limfjord, the North Sea and the Vendsyssel regions, and the Skagen area based on the Skagen III Well DGU File No. 1.287. The Late Quaternary, marine, shell-bearing molluscs, comprising 341 subfossil and recent species, are characterised from the point of view of climatic (i.e. Arctic, Subarctic, Boreal and Lusitanian) affinities and animal-sediment relationships. On this background the faunal and environmental evolution recorded in the $217 \mathrm{~m}$ long Skagen Well core is analysed and described. The mollusc assemblages in the Skagen sequence indicate a deeper-water facies during the Eemian, the Weichselian and the older Holocene in contrast to what hitherto was known in other parts of the Danish area during the Late Quaternary. For the Skagen Well the chronozones Preboreal/Boreal, Atlantic, Subboreal and Subatlantic can be identified by ${ }^{14} \mathrm{C}$ dating. The environmental changes within the seven regions through the Late Quaternary are evaluated by depicting the molluscan communities encountered in the seven Late Quaternary stages together with remarks on studies of the neighbouring areas. By following the marine communities through the Late Quaternary in the light of the classical bottom communities sensu C.G.J. Petersen, it is demonstrated how facies have changed both through time and space within the Danish marine realm. The wellestablished, more temperate Eemian marine fauna was closely associated with shallow-water environments. The inferred climatic changes reflect an interglacial-glacial cycle. However, the climatically induced changes during the Holocene in the marine environment were small and overshadowed by the facies changes. Out of the 341 species recorded in this study, 140 occur in the Eemian, 36 in the Early/Middle Weichselian and 41 in the Late Weichselian. The Holocene fauna is represented by 183 species of shell-bearing molluscs, of which the first recorded occurrence of 148 species has been radiocarbon-dated.

Author's address

Geological Survey of Denmark and Greenland, Øster Voldgade 10, DK-1350 Copenhagen K, Denmark. E-mail: ksp@geus.dk 


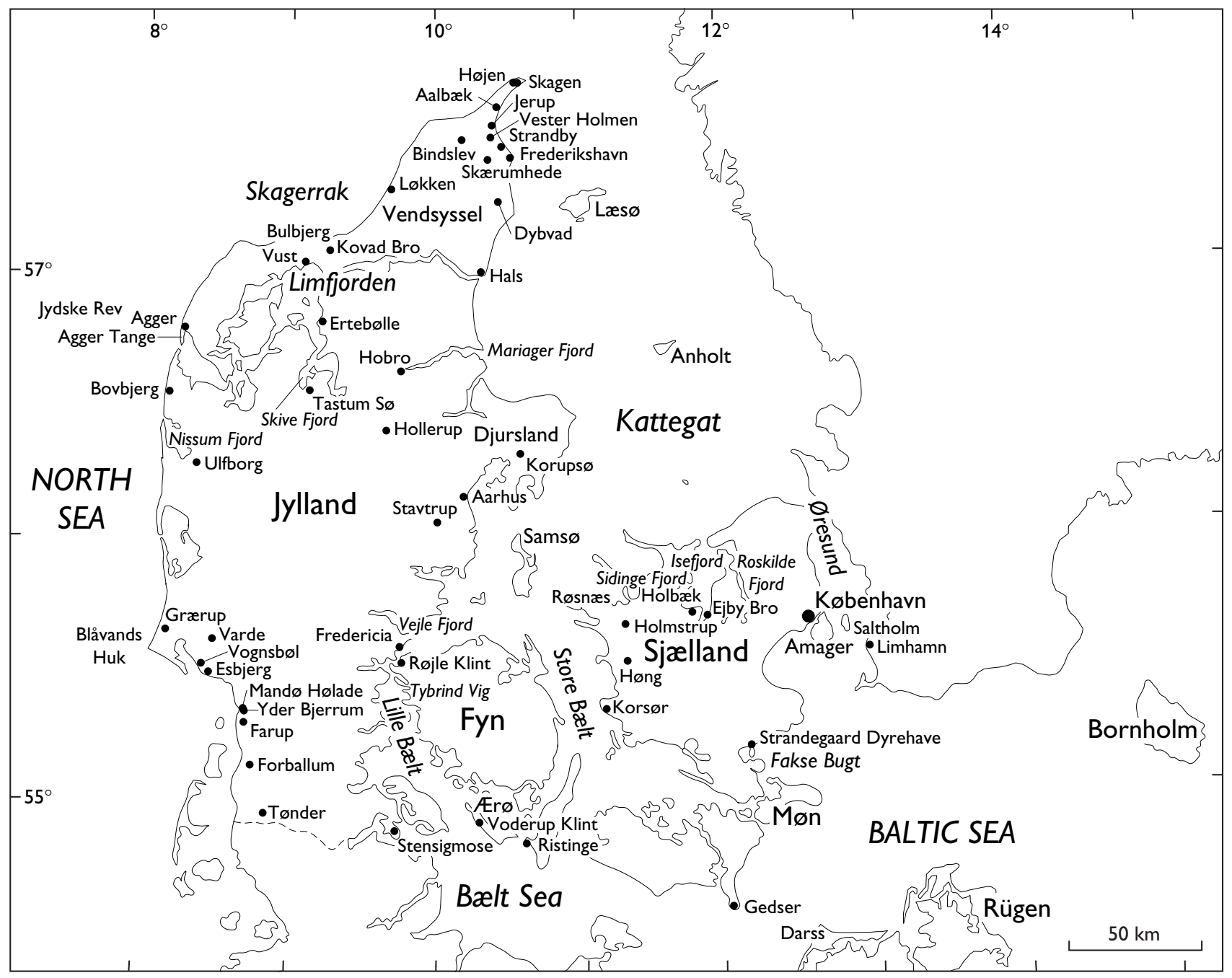

Fig. 1. Location map with Late Quaternary marine localities and names of areas on land and of Danish waters. 


\section{Introduction}

In the middle of 19th century, Denmark had its first 'Geology of Denmark' published by G. Forchhammer, in 1835. However, as Forchhammer expressed it in 1851 when making some notes on the work by the malacologist O.A.L. Mørch (1828-1878) at the Mineralogical Museum of Copenhagen. It has hitherto been enough for the geognost to establish formations using the characteristic fossils, but in the future we have to give a closer description from a zoological point of view (Petersen 1997, p. 5). Considering only the younger deposits, the efforts of the zoologist in geological works are highly significant and became important already in the 19th century. C.G.J. Petersen (1860-1928) is an outstanding example of such an influence with his work on the extent of shell-bearing molluscs in the Danish seas inside the Skagen (Petersen 1888, 1893). Here he points to the faunal conditions also in the Pleistocene and Holocene marine deposits compared to the recent distribution. In the description accompanying the geological map sheets of Vendsyssel (Jessen 1899), Jessen gives full credit to C.G.J. Petersen and A. Jensen (18661953) for their studies on the molluscan species recorded from that part of the country. Later both Petersen and Jensen contributed further to our knowledge of the marine molluscan fauna. Petersen formed the concept of the bottom communities (Petersen \& Jensen 1911; Petersen 1913, 1914, 1915, 1918) that has been the tool for further work, not only within the Danish waters but all over the world with the so-called parallel bottom communities (Thorson 1957). Though the concept of parallel molluscan communities in the sense of Thorson (1957) has been considerably modified in the last 30 years (Erwin 1983), there remains a recognition that particular molluscan assemblages are associated with various types of habitat. In 1899 the zoologist V. Nordmann (1872-1962) was engaged by the Geological Survey of Denmark to study the molluscs from the Quaternary deposits. Part of this work was already reflected in the next geological map sheet covering the southern part of Vendsyssel (Jessen 1905). Here Nordmann has identified the molluscs and given the faunal remarks on the Holocene marine fauna in the north-eastern part of the Limfjord (Fig. 1). In his work, the zoological considerations are given, elucidating the Holocene palaeoenvironments. However, from the beginning of the century Nordmann touched upon many other aspects within the Late Quaternary marine environments which form the most important base for the present study covering marine deposits from the Eemian, the Weichselian and the Holocene.

In the following chapter the presentation of some observed sites with marine sediments will be given as an introduction to an answer to the question raised by Petersen (1910, p. 29): "What I have often missed in the geological studies is a thorough or detailed comparison between the fossil faunas and the molluscan faunas now living before our eyes".

The aim of this work is to characterise the changing environments in the Danish waters through time as seen in the macrofaunas and bottom communities mainly based on molluscs.

\section{Danish sites with marine sediments}

Initially, the findings and descriptions of the Danish marine localities shown in Fig. 1 were part of the university studies pioneered by G. Forchhammer. However, since the start of the Geological Survey of Denmark in 1888, much of the information has come from the systematic mapping of Denmark, and the results have been published in the descriptions to the geological map sheets of Denmark (Fig. 2).
As seen from the plan for the geological mapping of Denmark (e.g. Sørensen \& Nielsen 1978) it was decided to do the mapping first in the northern parts of Jylland and Sjæelland and to present a record of the marine deposits from the areas mapped. Today, up to 80 per cent of the country has been mapped and descriptions for many map sheets have been published. The main information on the Holocene marine mol- 


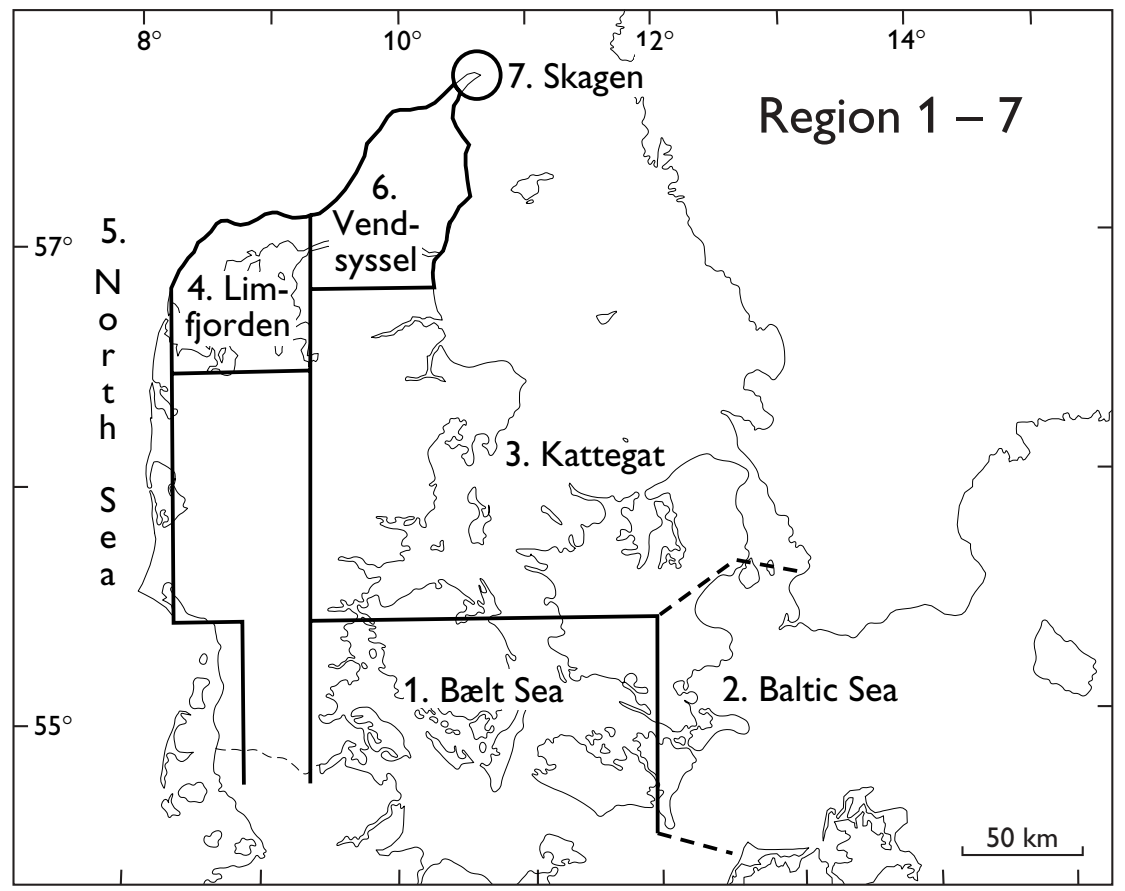

Fig. 2. The frame for the seven regions follows mainly the pattern of the old geological map sheets (Sørensen \& Nielsen 1978, fig. 1) and partly the regions used in Jensen \& Knudsen (1995, fig. 1).

1: The Bælt Sea covering the southern part of the Bæelts. 2: The Baltic covering the southern part of Øresund and east of Darss-Gedser. 3: The Kattegat region covering the northern part of the Bælts and Øresund. 4: The western Limfjord except the North Sea coastal region. 5: The North Sea with coastal regions and Skagerrak. 6: Vendsyssel including former marine areas. 7: Skagen, mainly the Skagen Well DGU File No. 1.287.

luscs is available in these publications and is used in the present description supplemented by specific molluscan studies within the areas.

Consequently, the frame will be the transition area between the North Sea and the Baltic and the descrip- tion mainly based on the geological map sheets found in the following regions shown in Fig. 2: (1) The Bæelt Sea; (2) The Baltic; (3) The Kattegat with bordering fjords; (4) The Limfjord; (5) The North Sea; (6) Vendsyssel and The Skagen Well III, DGU File No. 1, 287.

\section{The Late Pleistocene}

In 1841 Forchhammer found the Cyprina Clay to the southern part of Denmark, naming the unit after the dominating bivalve (Forchhammer 1842). First, however, Forchhammer referred the thick shell molluscs to Glossus bumanus rather than to Arctica islandica. Consequently, he placed the deposits in the 'Brunkulsformation', viz. the Tertiary. When finally realising that the common species was Arctica islandica, he transferred the deposits to the so-called 'Rullestensformation', viz. the Quaternary. Along with the investigations of the Cyprina clay through the years since 1841, the actual stratigraphical position was very much under debate, and it was not until 1928 when Nordmann wrote his La Position stratigraphique des Dépôts d'Eem that the Cyprina clay attained its final position: "appartenant à la dernière période interglaciaire" (Nordmann 1928, p. 65). Later the name 'Eemian' became the designation for the whole interglacial, according to Gripp (1964, pp. 215-216). Johnstrup (1882a) gave the first detailed description of the Cyprina Clay in Denmark and Slesvig. Also in the northern part of Denmark, Late Pleistocene deposits were studied by Johnstrup (1882b), but with references to the earlier works by Forchhammer (1822), Bredsdorff (1824), Faber (1828) and Pingel (1828). In 1908 Nordmann made his doctoral thesis on the molluscan fauna from the Cyprina Clay and other central European deposits, forming a part of the publication by Madsen et al. (1908).

The sequence of interglacial-glacial marine depos- 
Fig. 3. Stratigraphic framework for the Late Quaternary deposits from Pedersen \& Petersen (1997).

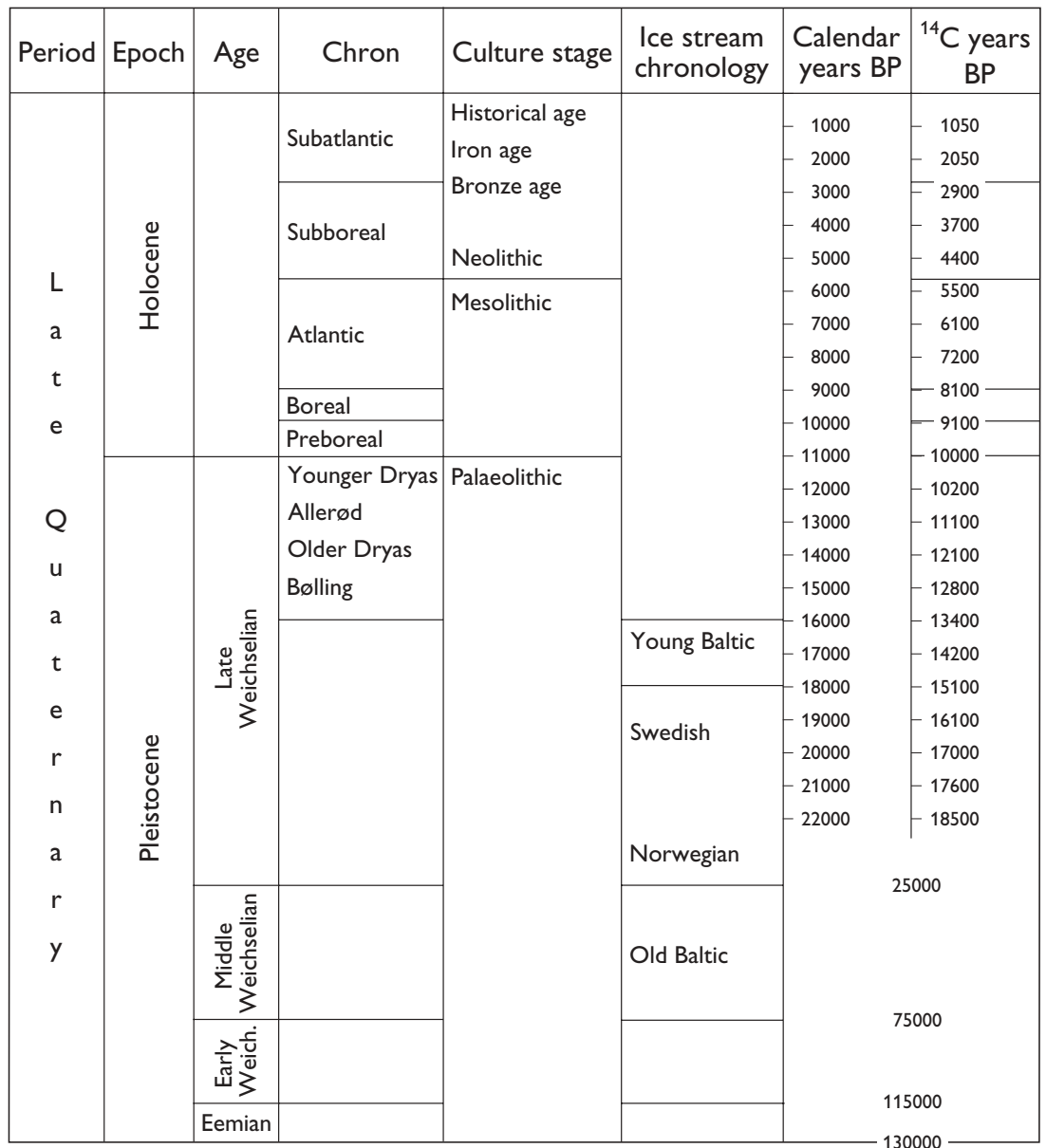

its is described from the well at Skærumhede (Jessen et al. 1910). Here the full Late Pleistocene record is found, although the stratigraphic position was not clear at that time. Later investigations, also with studies of the molluscan fauna, were published in 1974 and a Late Pleistocene age proposed (Bahnson et al. 1974). The difference between the Boreo-Lusitanian community in the boring and the typical Eemian community as found in southern Denmark was interpreted as difference in facies (Bahnson et al. 1974) (see Nilsson 1983).

In the study of the marine Late Pleistocene deposits in southern Denmark ( $\varnothing$ dum 1933) based on the record of molluscan species as determined by V. Nordmann the finds point to two different deposits in time. One is regarded as Eemian and the other as the so-called Skærumhede fauna. However, later investigations at Strandegaards Dyrehave in southern Sjælland (Petersen \& Konradi 1974) and at Holmstrup in central Sjælland (Fig. 1; Petersen \& Buch 1974), revealed that the molluscan species found at Strandegaards Dyrehave, one of the localities of Ødum (1933) and regarded as representing the Skærumhede fauna, could be Eemian but reflecting another facies than the typical Eemian on the islands south of Fyn. The Holmstrup fauna is to be correlated with the Arctic marine Weichselian in northern Jylland which is the upper part of the Portlandia arctica zone sensu Nordmann (Madsen et al. 1908) or the Macoma calcarea zone sensu Petersen (Bahnson et al. 1974, fig. 7), see Fig. 3 for stratigraphical position.

The aminostratigraphic investigations of the Danish Late Pleistocene deposits as published by Miller \& Mangerud (1985) sustain only to some extent the abovementioned correlations: "None of the sites regarded here as Eemian (Strandegaards Dyrehave) gave ratios as high as in Holsteinian deposits or as low as in Middle Weichselian deposits" (Miller \& Mangerud 1985, p. 261). In the case of the Holmstrup Weichselian site, only three out of eleven individuals of Macoma calcarea gave Weichselian ratios (Miller \& Mangerud 1985, p. 264).

The marine molluscan fauna of the Late Weichselian has been studied intensively only from the Vend- 
syssel area recorded in the publications by Jessen (1899, 1936). Nearly 30 molluscan samples from these Late Weichselian - Younger Yoldia Sea deposits have been dated (Krog \& Tauber 1974).

The evaluation of the molluscan communities in Vend- syssel reveals the changing Late Weichselian sea level (Petersen 1984), and the highest marine shoreline, around $60 \mathrm{~m}$ a.s.l., in northern Denmark can be shown to develop between 14000 and 13000 B.P. $\left({ }^{14} \mathrm{C}\right.$ years $)$.

\section{The Holocene}

Forchhammer participated in the work of the so-called 'Lejrekomité', an interdisciplinary committee studying human remains along the shore. This commission gave the first - and now famous - description of the 'køkkenmødding' (kitchen midden), a mound consisting of shells of edible molluscs and other refuse, marking the site of a prehistoric human habitation (Hanks 1971). 'Køkkenmødding' is one of the few Danish international terms (Forchhammer et al. 1851). The work of the 'Lejrekomité' was concentrated on the marine molluscs in order to establish out whether the shell deposits were naturally based - oyster banks - or whether they were formed as waste deposits produced by men living at coastal sites.

The other members of the commission were $\mathrm{J}$. Worsaae and J. Steenstrup, representing archaeology and zoology respectively. Consistently, the study of the molluscan elements was based mainly on Steenstrup's work. However, while working in the commis- sion, Forchhammer continued his studies on the sea levels (Forchhammer 1838, 1840). This was essential for the discussion of whether the molluscs found belonged to raised marine deposits or were gathered by man. Forchhammer's study led to the concept of raised marine deposits north of a line from Nissum Fjord to south of Korsør in the Storebælt area (Fig. 1). This line still carries the name of Forchhammer and divides the country into two parts, with the raised marine areas to the north-east, and to the south-west the area where the land has been sinking. Together with the study of the Holocene molluscan fauna by Johnstrup (1882b), such observations on shorelines were also collected. It became one of the points specially mentioned in the instructions for the autographic geologists when the systematic geological mapping of Denmark was started in 1888 by the Geological Survey of Denmark (Sørensen \& Nielsen 1978)

\section{The recent fauna of shell-bearing molluscs compared to the subfossil fauna}

The record of recent Danish shell-bearing molluscs has been taken from the annotated check list of recent marine molluscs of Danish waters (Jensen \& Knudsen 1995). In Appendix 1 the species are presented taxonomically following Jensen \& Knudsen (1995). Late immigrants from the last centuries - transferred by man - have been omitted from the list, because the aim of the present study is to present the development in the subfossil Late Quaternary molluscan fauna also in Ap- pendix 1 compared to the natural fauna of today. According to Fredén (1986), subfossil means that the weight of the object when found does not exceed its original weight, which is obviously the case for younger deposits seen geologically as shells from the Late Quaternary.

In all, 278 recent species of shell-bearing molluscs are recorded from the Danish waters:

The Class Polyplacophora is represented by seven 
Fig. 4. Regional division of the European seas from Feyling-Hanssen (1955).

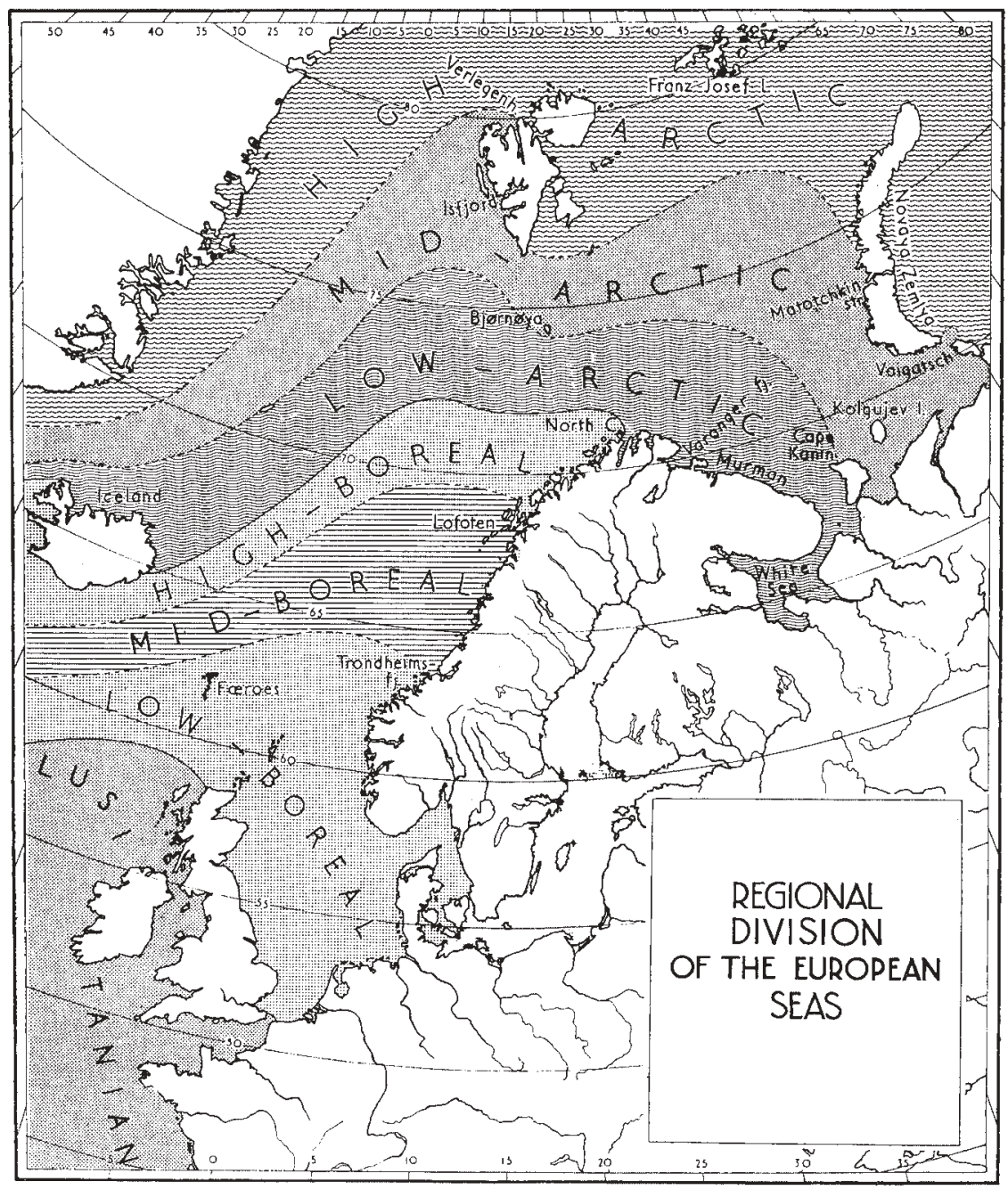

species forming $2.5 \%$ of the total number of known species.

The Class Gastropoda is represented by 151 species forming $54.3 \%$ of the total number of known species.

The Class Scaphopoda is represented by three species forming $1.1 \%$ of the total number of known species.

The Class Bivalvia is represented by 117 species forming $42.1 \%$ of the total number of known species.

The list of known finds of subfossil species amounts to 247 species. With regard to the classes, it appears that Polyplacophora is now represented by only one species, which formed $0.4 \%$ of the total subfossil molluscan species.

Within the Class Gastropoda 125 species occur, forming $50.6 \%$ of the total number of subfossil species, a figure which is nearly $5 \%$ lower than that for recent gastropods.
The Class Scaphopoda is represented by five fossil species which form $2.0 \%$ of the subfossil shell-bearing species which is a little higher than the ratio for the recent fauna.

The Class Bivalvia is represented by 116 species forming $47.0 \%$ of the total, which is a little more than $7 \%$ above the recent ratio.

The low number of subfossil Polyplacophora can be explained by the fact that the shells from those species are nearly always broken, and this excludes identification to species level, so to say, following the statement made by Knudsen (1970, p. 1): "Isolated and worn plates were neglected altogether".

Among the Gastropods, the subclasses and orders, except the Order Heterostropha within the subclass Heterobranchia, have a lower representation of subfossil finds than of recent ones. The Heterostropha, which has a $2.5 \%$ higher representation among the subfossil finds than among the recent ones, is a group 


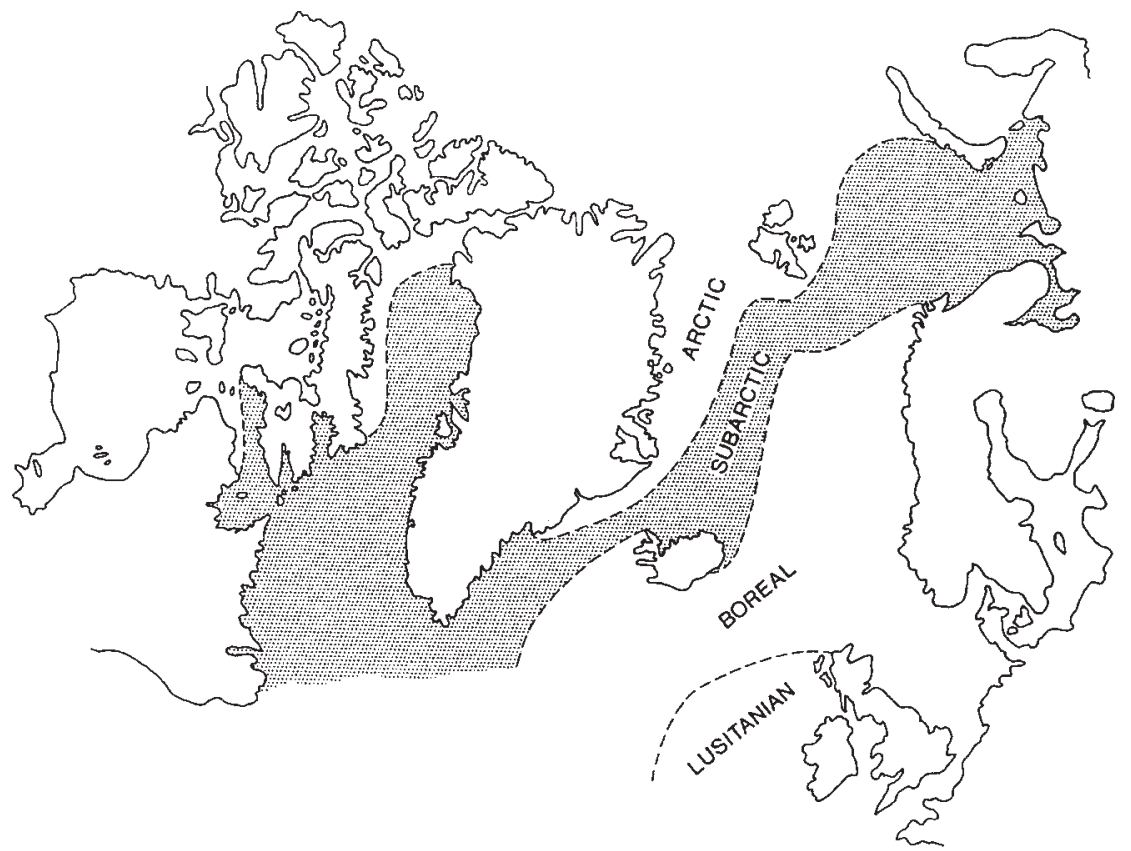

Fig. 5. Regional division of the European seas according to Símonarson et al. (1998).

of mostly tiny specimens which might be more looked for in the geological samples than in the recent bottom samples often used in the more practical work of evaluation benthos introduced by C.G.J. Petersen. However, many of these small species should be considered with the utmost care, with respect to the difficulty of identifying them to species level within subfossil material.

The reason why the Class Scaphopoda has a twice as great a representation within the subfossil material cannot be given, although it is tempting to regard the different palaeoenvironment back in the Late Quaternary as the explanation of the higher frequency. The greater variety of palaeoenvironment and different climate back in time is clearly the reason why the Bivalvia within all subclasses has a higher percentage than in the recent fauna.

However, as an overview, the total subfossil species could be compared to the recent ones arranged also after their climatic affinities, as will be thoroughly discussed in one of the following chapters. With respect to distribution of molluscan species within the North Atlantic - West European realm, four zones may be distinguished, viz.: the Arctic $=\mathrm{a}$, the Subarctic $=\mathrm{s}$, the Boreal $=\mathrm{b}$ and the Lusitanian $=1($ Figs 4,5$)$.

It appears from the comparison between subfossil species and recent species sorted after climatic affinity (Appendix 1) that the subfossil species have their dominance in the extreme groups, i.e. Arctic $=\mathrm{a}$; Arctic/ Subarctic $=$ as; Arctic, Subarctic and Boreal $=$ asb and
Subarctic/Boreal, while the species with a wide tolerance - Arctic, Subarctic, Boreal and Lusitanian = asbl have a higher representation within the recent fauna.

Also the middle group, which is represented by faunal element from the Subarctic, Boreal and Lusitanian, the Boreal and Lusitanian (which is the most numerous group with 140 subfossil species) has a higher representation in the recent fauna. But the group of purely Lusitanian species has a clearly better representation among the subfossil species, as seen by the percentage figure $6.2 \%$ compared to $0.7 \%$ for the purely Lusitanian faunal elements among the subfossil and recent faunas respectively.

These observations reveal that the Late Quaternary fauna covers a period of 130000 years with changing climatic conditions both with colder and warmer periods than at present.

So considering the totals of subfossil and recent species one has to discuss the difference not only quantitatively but qualitatively; because only 184 species are shared between the Late Quaternary and the recent finds, while 63 species have to be considered as particular ones occurring within the Late Quaternary during the Eemian, the Weichselian or the Holocene, in one, two or in all three groups but not the recent one.

Within the Bivalvia, the highest amount of subfossil species (31) found only in the Late Quaternary occur. Such species are also the species which must be focused on in the evaluation of the changing environment through time. 


\section{Molluscan finds within the seven regions during the Holocene}

The molluscan finds within each region (see Fig. 2) from the Holocene, as appearing mainly from the descriptions accompanying the geological map sheets of Denmark, are presented.

\section{The Brelt Sea area}

From the Brelt Sea area the information on the occurrences of molluscs has been taken from the following map sheets: Madsen (1902) and Jessen (1907 (contributions by V. Nordmann), 1935, 1945); V. Milthers (1940) and K. Milthers (1959). Nordmann (1906) has a record of molluscs found in Skælskør Nor (SW Sjælland) and Petersen records from the areas south of Fyn, Storebælt and Lillebælt (1985c, 1989).

Subfossil Holocene species in the Bæelt Sea area

Class Gastropoda
Subclass Prosobranchia
Order Neotaenioglossa
Littorina littorea (Linnaeus 1758)
Littorina obtusata (Linnaeus 1758)
Littorina saxatilis (Olivi 1792)
Littorina tenebrosa (Montagu 1803)
Lacuna pallidula (da Costa 1778)
Lacuna vincta (Montagu 1803)
Hydrobia ulvae (Pennant 1777)
Hydrobia ventrosa (Montagu 1803)
Onoba semicostata (Montagu 1803)
Rissoa albella Lovén 1846
Rissoa inconspicua Alder 1844
Rissoa membranacea (J. Adams 1800)
Bittium reticulatum (da Costa 1778)
Order Heterogastropoda
Triphora adversa (Montagu 1803)
Order Neogastropoda
Hinia reticulata (Linnaeus 1758)
Subclass Heterobranchia
Order Heterostropha
Omalogyra atomus (Phillippi 1841)
Odostomia conoidea Winckworth 1932
Subclass Opisthobranchia
Order Anaspidea
Retusa obtusa (Montagu 1803)

Retusa truncatula (Bruguière 1792)

Akera bullata Müller 1776

Subclass Pulmonata

Order Basommatophora

Lymnaea peregra (Müller 1774)

Class Bivalvia

Subclass Pteriomorpha

Order Mytiloida

Mytilus edulis Linnaeus 1758

Modiolula phaseolina (Philippi 1844)

Modiolus modiolus (Linnaeus 1758)

Musculus discors (Linnaeus 1767)

Order Pterioida

Ostrea edulis Linnaeus 1758

Subclass Heterodonta

Order Veneroida

Mysella bidentata (Montagu 1803)

Tridonta borealis Schumacher 1817

Parvicardium exiguum (Gmelin 1791)

Parvicardium ovale (Sowerby 1840)

Parvicardium scabrum (Philippi 1844)

Cerastoderma edule (Linnaeus 1758)

Spisula subtruncata (da Costa 1778)

Angulus tenuis (da Costa 1778)

Macoma baltbica (Linnaeus 1758)

Scrobicularia plana (da Costa 1778)

Abra alba (Wood 1802)

Arctica islandica (Linnaeus 1767)

Paphia aurea (Gmelin 1791)

Tapes decussatus (Linnaeus 1758)

Venerupis pullastra (Montagu 1803)

Order Myoida

Mya arenaria Linnaeus 1758

Mya truncata Linnaeus 1758

Corbula gibba (Olivi 1792)

Hiatella arctica (Linnaeus 1758)

Barnea candida (Linnaeus 1758)

Zirfaea crispata (Linnaeus 1758)

Total for the Holocene Bælt Sea: 47 (19.0\%) 


\section{The Baltic area}

The Baltic area is here restricted to the area east of Darss and south of Øresund at Saltholm, which must be considered the Baltic sensu stricto when regarding the present distribution of the marine fauna and also taking into consideration the subfossil Holocene molluscan fauna, as will be demonstrated by a following comparison with the other areas. The main map sheet published is by V. Milthers from 1908 with contributions by V. Nordmann on the Holocene molluscan fauna. The subfossil Holocene fauna has also been studied later in the western part by Petersen (1994b). In the description accompanying the map sheet Bornholm (Grönwall \& Milthers 1916) there is no record of a mollusc fauna.

Subfossil Holocene species in the Baltic area

Class Gastropoda

Subclass Prosobranchia

Order Neotaenioglossa

Littorina littorea (Linnaeus 1758)

Littorina tenebrosa (Montagu 1803)

Hydrobia ulvae (Pennant 1777)

Hydrobia ventrosa (Montagu 1803)

Rissoa albella Lovén 1846

Rissoa inconspicua Alder 1844

Rissoa membranacea (J. Adams 1800)

Bittium reticulatum (da Costa 1778)

Aporrbais pespelicani (Linnaeus 1758)

Order Neogastropoda

Hinia reticulata (Linnaeus 1758)

Subclass Opisthobranchia

Order Anaspidea

Retusa truncatula (Bruguière 1792)

Subclass Pulmonata

Order Basommatophora Lymnaea peregra (Müller 1774)

Class Bivalvia

Subclass Pteriomorpha

Order Mytiloida Mytilus edulis Linnaeus 1758

Subclass Heterodonta

Order Veneroida

Parvicardium exiguum (Gmelin 1791)

Cerastoderma edule (Linnaeus 1758)

Cerastoderma glaucum (Poiret 1789)

Macoma balthica (Linnaeus 1758)

Scrobicularia plana (da Costa 1778)

Order Myoida

Corbula gibba (Olivi 1792)

Total for the Holocene Baltic: 19 (7.7\%)

\section{The Kattegat area with fjords}

The Kattegat area sensu lato includes the fjords, i.e. the northern part of the Lillebælt area, Storebælt and Øresund. Therefore the following map sheets are taken within this area:

1. The north-eastern part of Sjælland described by Rørdam (1893), who published a detailed description of the Holocene marine deposits from northeast Sjælland already in 1891 and continued with the description of the map sheet København and Roskilde (1899) where the southernmost parts of the Roskilde Fjord and the Øresund are described in great detail for the marine Holocene part.

2. Furthermore, Rørdam \& V. Milthers published the description for the geological map sheet of NW Sjælland in 1900 and Nordmann on the molluscs in Sidinge fjord (Westerby 1933).

3. From the north-western part of Fyn and the island of Sams $\varnothing$ by Madsen $(1897,1900)$ and together with Ussing for the north-eastern part of Fyn (Ussing \& Madsen 1897).

4. The map sheet of Fredericia (Nordmann 1958) covers the northern part of the Lillebælt and Vejle Fjord on the eastern coast of Jylland.

5. From the islands of Læs $\varnothing$ and Anholt in the Kattegat the description was given by Jessen (1897) and Nordmann (1903a).

6. From Hobro by Nordmann (Jessen 1927).

7. From Mariager Fjord by Nordmann (Ødum 1929).

8. The peninsula of Djursland has been mapped during the last decades, and the description of the Holocene marine molluscan fauna is by Petersen (Pedersen \& Petersen 1997) and Petersen (1993).

Subfossil Holocene species in the Kattegat

Class Gastropoda

Subclass Prosobranchia

Order Archaeogastropoda

Theodoxus fluviatilis (Linnaeus 1758)

Order Neotaenioglossa

Littorina littorea (Linnaeus 1758)

Littorina obtusata (Linnaeus 1758)

Littorina saxatilis (Olivi 1792)

Littorina tenebrosa (Montagu 1803)

Lacuna vincta (Montagu 1803)

Hydrobia ulvae (Pennant 1777)

Hydrobia ventrosa (Montagu 1803)

Skeneopsis planorbis (Fabricius 1780)

Onoba semicostata (Montagu 1803)

Onoba vitrea (Montagu 1803) 
Rissoa albella Lovén 1846

Rissoa inconspicua Alder 1844

Rissoa membranacea (J. Adams 1800)

Bittium reticulatum (da Costa 1778)

Order Heterogastropoda

Triphora adversa (Montagu 1803)

Order Neogastropoda

Buccinum undatum Linnaeus 1758

Hinia reticulata (Linnaeus 1758)

Subclass Heterobranchia

Order Heterostropha

Omalogyra atomus (Phillippi 1841)

Brachystomia eulimoides Hanley 1844

Chrysallida spiralis (Montagu 1803)

Subclass Opisthobranchia

Order Anaspidea

Retusa obtusa (Montagu 1803)

Retusa truncatula (Bruguière 1792)

Akera bullata Müller 1776

Class Bivalvia

Subclass Pteriomorpha

Order Mytiloida

Mytilus edulis Linnaeus 1758

Musculus discors (Linnaeus 1767)

Order Pterioida

Heteranomia squamula (Linnaeus 1758)

Ostrea edulis Linnaeus 1758

Subclass Heterodonta

Order Veneroida

Mysella bidentata (Montagu 1803)

Acanthocardia echinata (Linnaeus 1758)

Parvicardium exiguum (Gmelin 1791)

Parvicardium scabrum (Philippi 1844)

Cerastoderma edule (Linnaeus 1758)

Cerastoderma glaucum (Poiret 1798)

Macoma balthica (Linnaeus 1758)

Scrobicularia plana (da Costa 1778)

Abra alba (Wood 1802)

Arctica islandica (Linnaeus 1767)

Paphia aurea (Gmelin 1791)

Tapes decussatus (Linnaeus 1758)

Venerupis pullastra (Montagu 1803)

Order Myoida

Mya arenaria Linnaeus 1758

Mya truncata Linnaeus 1758

Corbula gibba (Olivi 1792)

Hiatella rugosa (Linnaeus 1758)

Total for the Holocene Kattegat: 45 (18.2\%)

\section{The Limfjord area}

From the Limfjord area (western part), excluding the part which falls within Vendsyssel, only one description for a map sheet has been published (Gry 1979). However, the molluscs are recorded in publications by Petersen (1976, 1981, 1985a, 1986a) and in Rasmussen \& Petersen (1980). Furthermore, V. Nordmann collected Holocene marine shells from the western Limfjord in 1902-1903 which were further examined by Erna Nordmann and Leifur Símonarson in the sixties as mentioned in Petersen (1976, p. 78). It must be emphasised that C.G.J. Petersen in 1888 discussed the subfossil fauna also from the Limfjord, which was earlier the topic of Collin (1884).

Subfossil Holocene species in the Limfjord

Class Gastropoda

Subclass Prosobranchia

Order Archaeogastropoda

Patella vulgata Linnaeus 1758

Helcion pellucidum (Linnaeus 1758)

Iotbia fulva (Müller 1776)

Acmaea tessulata (Müller 1776)

Acmaea virginea (Müller 1776)

Margarites belicinus (Phipps 1774)

Gibbula cineraria (Linnaeus 1758)

Gibbula tumida (Montagu 1803)

Skenea serpuloides (Montagu 1808)

Skenea basistriata (Jeffreys 1877)

Order Neotaenioglossa

Littorina littorea (Linnaeus 1758)

Littorina obtusata (Linnaeus 1758)

Littorina saxatilis (Olivi 1792)

Littorina tenebrosa (Montagu 1803)

Lacuna pallidula (da Costa 1778)

Lacuna parva (Montagu 1803)

Lacuna vincta (Montagu 1803)

Hydrobia ulvae (Pennant 1777)

Hydrobia ventrosa (Montagu 1803)

Skeneopsis planorbis (Fabricius 1780)

Alvania lactea (Michaud 1830)

Alvania punctura (Montagu 1803)

Cingula semistriata (Montagu 1808)

Onoba semicostata (Montagu 1803)

Onoba proxima (Forbes \& Hanley 1850)

Onoba vitrea (Montagu 1803)

Rissoa albella Lovén 1846

Rissoa inconspicua Alder 1844

Rissoa membranacea (J. Adams 1800)

Rissoa parva (da Costa 1779)

Rissoa violacea Desmarest 1814 
Caecum glabrum (Montagu 1803)

Bittium reticulatum (da Costa 1778)

Turritella communis Risso 1826

Aporrhais pespelicani (Linnaeus 1758)

Lunatia alderi (Forbes 1838)

Lunatia catena (da Costa 1778)

Order Heterogastropoda

Triphora adversa (Montagu 1803)

Cerithiopsis barleei (Jeffreys 1867)

Cerithiopsis tubercularis (Montagu 1803)

Epitonium clatbrus (Linnaeus 1758)

Epitonium turtonis (Turton 1819)

Aclis minor (Brown 1827)

Vitreolina philippii (Rayneval \& Ponzi 1854)

Order Neogastropoda

Nucella lapillus (Linnaeus 1758)

Buccinum undatum Linnaeus 1758

Hinia incrassata (Ström 1768)

Hinia pygmaea (Lamarck 1822)

Hinia reticulata (Linnaeus 1758)

Oenopota turricola (Montagu 1803)

Raphitoma purpurea (Montagu 1803)

Raphitoma linearis (Montagu 1803)

Subclass Heterobranchia

Order Heterostropha

Omalogyra atomus (Phillippi 1841)

Brachystomia eulimoides Hanley 1844

Odostomia scalaris MacGillivray 1843

Chrysallida decussata (Montagu 1803)

Chrysallida eximia (Jeffreys 1849)

Chrysallida indistincta (Montagu 1808)

Chrysallida obtusa (Brown 1827)

Chrysallida spiralis (Montagu 1803)

Ebala nitidissima (Montagu 1803)

Eulimella laevis (Brown 1827)

Eulimella scillae (Scacchi 1835)

Ondina divisa (J. Adams 1797)

Ondina diaphana (Jeffreys 1848)

Odostomia acuta Jeffreys 1848

Odostomia conoidea Winckworth 1932

Odostomia turrita Hanley 1844

Odostomia albella Lovén 1846

Odostomia plicata (Montagu 1803)

Turbonilla crenata (Brown 1827)

Turbonilla delicata (Monterosato 1874)

Turbonilla lactea (Linnaeus 1758)

Subclass Opisthobranchia

Order Bullomorpha

Acteon tornatilis (Linnaeus 1758)

Cylichna cylindracea (Pennant 1777)

Cylichna alba (Brown 1827)
Philine aperta (Linnaeus 1767)

Philine punctata (Adams 1800)

Order Anaspidea

Diaphana minuta Brown 1827

Retusa obtusa (Montagu 1803)

Retusa truncatula (Bruguière 1792)

Retusa umbilicata (Montagu 1803)

Akera bullata Müller 1776

Class Bivalvia

Subclass Palaeotaxodonta

Order Nuculoida

Nucula nitidosa Winckworth 1930

Nucula nucleus (Linnaeus 1767)

Nuculoma tenuis (Montagu 1808)

Subclass Pteriomorpha

Order Mytiloida

Mytilus edulis Linnaeus 1758

Modiolula phaseolina (Philippi 1844)

Modiolus adriaticus (Lamarck 1819)

Modiolus modiolus (Linnaeus 1758)

Musculus discors (Linnaeus 1767)

Modiolaria tumida (Hanley 1843)

Order Pterioida

Aequipecten opercularis (Linnaeus 1758)

Chlamys varia (Linnaeus 1758)

Delectopecten vitreus (Gmelin 1791)

Palliolum striatum (Müller 1776)

Palliolum tigerinum (Müller 1776)

Pododesmus patelliformis (Linnaeus 1761)

Anomia ephippium Linnaeus 1758

Heteranomia squamula (Linnaeus 1758)

Ostrea edulis Linnaeus 1758

Subclass Heterodonta

Order Veneroida

Lucinoma borealis (Linnaeus 1758)

Thyasira flexuosa (Montagu 1803)

Mysella bidentata (Montagu 1803)

Tellimya ferruginosa (Montagu 1803)

Turtonia minuta (Fabricius 1780)

Lepton nitidum (Turton 1822)

Tridonta borealis Schumacher 1817

Acanthocardia echinata (Linnaeus 1758)

Parvicardium exiguum (Gmelin 1791)

Parvicardium ovale (Sowerby 1840)

Parvicardium scabrum (Philippi 1844)

Cerastoderma edule (Linnaeus 1758)

Cerastoderma glaucum (Poiret 1789)

Mactra stultorum (Linnaeus 1758)

Lutraria lutraria (Linnaeus 1758)

Spisula elliptica (Brown 1827)

Spisula solida (Linnaeus 1758) 
Spisula subtruncata (da Costa 1778)

Ensis ensis (Linnaeus 1758)

Phaxas pellucidus (Pennant 1777)

Angulus tenuis (da Costa 1778)

Fabulina fabula (Gmelin 1791)

Macoma balthica (Linnaeus 1758)

Donax vittatus (da Costa 1778)

Gari fervensis (Gmelin 1791)

Scrobicularia plana (da Costa 1778)

Abra alba (Wood 1802)

Abra nitida (Müller 1776)

Abra prismatica (Montagu 1803)

Arctica islandica (Linnaeus 1767)

Chamelea striatula (da Costa 1778)

Clausinella fasciata (da Costa 1778)

Paphia aurea (Gmelin 1791)

Tapes decussatus (Linnaeus 1758)

Timoclea ovata (Pennant 1777)

Venerupis rhomboides (Pennant 1777)

Venerupis pullastra (Montagu 1803)

Mysia undata (Pennant 1777)

Order Myoida

Mya truncata Linnaeus 1758

Corbula gibba (Olivi 1792)

Hiatella arctica (Linnaeus 1758)

Saxicavella jeffreysi Winckworth 1930

Barnea candida (Linnaeus 1758)

Pholas dactylus Linnaeus 1758

Zirfaea crispata (Linnaeus 1758)

Subclass Anomalodesmata

Order Pholadomyoida

Thracia phaseolina (Lamarck 1818)

Total for the Holocene Limfjord: 147 (59.5\%)

\section{The North Sea}

In the North Sea region the map sheet Blaavands Huk (Fig. 1) forms the southernmost part of what is covered by the present presentation regarding the Holocene deposits, and this area was described by Jessen (1925). Nordmann (in Jessen 1925) contributed with the study of the molluscs.

1. In the work by Petersen (1985a) the molluscan fauna in the coastal region - the Aggertange - is recorded.

2. The geological map sheet from Ulfborg was published by Petersen et al. (1992a), and the molluscan fauna treated by Petersen, but not yet published, is included.
3. In 1994 the Holocene molluscs from the Jydske Rev were studied and reported in a work for the Danish Coastal Authority (Petersen 1994a), and with minor corrections published in Petersen (1998).

Subfossil Holocene species in the North Sea

Class Gastropoda

Subclass Prosobranchia

Order Archaeogastropoda Gibbula cineraria (Linnaeus 1758) Theodoxus fluviatilis (Linnaeus 1758)

Order Neotaenioglossa Littorina littorea (Linnaeus 1758) Littorina obtusata (Linnaeus 1758) Littorina saxatilis (Olivi 1792) Lacuna pallidula (da Costa 1778) Lacuna parva (Montagu 1803) Lacuna vincta (Montagu 1803) Hydrobia ulvae (Pennant 1777) Hydrobia ventrosa (Montagu 1803) Cingula turgida (Jeffreys 1870) Onoba vitrea (Montagu 1803)

Rissoa albella Lovén 1846

Rissoa inconspicua Alder 1844

Rissoa membranacea (J. Adams 1800)

Rissoa violacea Desmarest 1814

Caecum glabrum (Montagu 1803)

Bittium reticulatum (da Costa 1778)

Turritella communis Risso 1826

Aporrhais pespelicani (Linnaeus 1758)

Lunatia alderi (Forbes 1838)

Lunatia catena (da Costa 1778)

Order Heterogastropoda

Triphora adversa (Montagu 1803)

Epitonium clatbrus (Linnaeus 1758)

Aclis ascaris (Turton 1819)

Aclis minor (Brown 1827)

Aclis walleri Jeffreys 1867

Order Neogastropoda

Nucella lapillus (Linnaeus 1758)

Buccinum undatum Linnaeus 1758

Hinia pygmaea (Lamarck 1822)

Hinia reticulata (Linnaeus 1758)

Subclass Heterobranchia

Order Heterostropha

Brachystomia eulimoides Hanley 1844 Chrysallida indistincta (Montagu 1808)

Chrysallida spiralis (Montagu 1803)

Eulimella laevis (Brown 1827)

Ondina diaphana (Jeffreys 1848)

Odostomia conoidea Winckworth 1932 
Odostomia albella Lovén 1846

Turbonilla crenata (Brown 1827)

Turbonilla delicata (Monterosato 1874)

Turbonilla lactea (Linnaeus 1758)

Subclass Opisthobranchia

Order Bullomorpha

Acteon tornatilis (Linnaeus 1758)

Cylichna alba (Brown 1827)

Order Anaspidea

Retusa obtusa (Montagu 1803)

Retusa truncatula (Bruguière 1792)

Retusa umbilicata (Montagu 1803)

Class Bivalvia

Subclass Palaeotaxodonta

Order Nuculoida

Nucula nitidosa Winckworth 1930

Nucula nucleus (Linnaeus 1767)

Nucula sulcata (Bronn 1831)

Nuculoma tenuis (Montagu 1808)

Subclass Pteriomorpha

Order Mytiloida

Mytilus edulis Linnaeus 1758

Musculus discors (Linnaeus 1767)

Order Pterioida

Chlamys varia (Linnaeus 1758)

Heteranomia squamula (Linnaeus 1758)

Ostrea edulis Linnaeus 1758

Subclass Heterodonta

Order Veneroida

Thyasira flexuosa (Montagu 1803)

Mysella bidentata (Montagu 1803)

Tellimya ferruginosa (Montagu 1803)

Lepton nitidum (Turton 1822)

Acanthocardia echinata (Linnaeus 1758)

Parvicardium exiguum (Gmelin 1791)

Parvicardium ovale (Sowerby 1840)

Parvicardium scabrum (Philippi 1844)

Parvicardium minimum (Philippi 1836)

Cerastoderma edule (Linnaeus 1758)

Mactra stultorum (Linnaeus 1758)

Spisula elliptica (Brown 1827)

Spisula solida (Linnaeus 1758)

Spisula subtruncata (da Costa 1778)

Ensis ensis (Linnaeus 1758)

Phaxas pellucidus (Pennant 1777)

Angulus tenuis (da Costa 1778)

Fabulina fabula (Gmelin 1791)

Macoma balthica (Linnaeus 1758)

Donax vittatus (da Costa 1778)

Scrobicularia plana (da Costa 1778)

Abra alba (Wood 1802)

\author{
Abra nitida (Müller 1776) \\ Arctica islandica (Linnaeus 1767) \\ Chamelea striatula (da Costa 1778) \\ Clausinella fasciata (da Costa 1778) \\ Paphia aurea (Gmelin 1791) \\ Tapes decussatus (Linnaeus 1758) \\ Timoclea ovata (Pennant 1777) \\ Venerupis pullastra (Montagu 1803) \\ Dosinia exoleta (Linnaeus 1758) \\ Dosinia lincta (Montagu 1803) \\ Order Myoida \\ Mya truncata Linnaeus 1758 \\ Corbula gibba (Olivi 1792) \\ Hiatella arctica (Linnaeus 1758) \\ Saxicavella jeffreysi Winckworth 1930 \\ Barnea candida (Linnaeus 1758) \\ Zirfaea crispata (Linnaeus 1758) \\ Subclass Anomalodesmata \\ Order Pholadomyoida \\ Cochlodesma praetenue (Pulteney 1799) \\ Thracia phaseolina (Lamarck 1818)
}

Total for the Holocene North Sea: 95 (38.5\%)

\section{The Vendsyssel area}

The Vendsyssel area includes the description accompanying the map sheets over the northern, central and southern parts, all by Jessen $(1899,1905)$, but with a contribution by V. Nordmann, who wrote the part on the Holocene molluscan fauna in the latter publication.

In this description by Nordmann he presents the different faunal communities as discovered in the subfossil assemblages. It was Nordmann's intention to continue the work further west into the western Limfjord area, but his first investigations were not used in the systematic geological mapping. They were, however, of great importance for the understanding of the development of the Holocene molluscan fauna (Nordmann 1910, 1918).

In 1928 in connection with the International Congress in Copenhagen a final overview by Nordmann of the Quaternary marine deposits in Denmark was given in the Summary of the Geology of Denmark (Madsen et al. 1928). Here Nordmann points to the Dosinia layers first described at the beginning of the century from Vendsyssel (Nordmann 1904), with a record of a fauna not found in the older Tapes beds originally demonstrated by Petersen (1888). 
Later investigations by Lauersen (1937) and Petersen (1990,1991a, b, 1992) on the Dosinia beds at Strandby are also included in the list of Holocene marine molluscs from Vendsyssel.

In Just Pedersen's thesis on Holocene molluscs from 1976 (unpublished), a new fauna element Donax vittatus in the Dosinia beds is recorded from Frederikshavn.

Subfossil Holocene species in the Vendsyssel

Class Gastropoda

Subclass Prosobranchia

Order Archaeogastropoda

Helcion pellucidum (Linnaeus 1758)

Acmaea virginea (Müller 1776)

Gibbula cineraria (Linnaeus 1758)

Gibbula tumida (Montagu 1803)

Order Neotaenioglossa

Littorina littorea (Linnaeus 1758)

Littorina obtusata (Linnaeus 1758)

Littorina saxatilis (Olivi 1792)

Littorina tenebrosa (Montagu 1803)

Lacuna pallidula (da Costa 1778)

Lacuna parva (Montagu 1803)

Lacuna vincta (Montagu 1803)

Hydrobia ulvae (Pennant 1777)

Skeneopsis planorbis (Fabricius 1780)

Alvania lactea (Michaud 1830)

Alvania cimicoides (Forbes 1844)

Alvania punctura (Montagu 1803)

Cingula semistriata (Montagu 1808)

Onoba semicostata (Montagu 1803)

Onoba vitrea (Montagu 1803)

Rissoa albella Lovén 1846

Rissoa inconspicua Alder 1844

Rissoa membranacea (J. Adams 1800)

Rissoa parva (da Costa 1779)

Rissoa violacea Desmarest 1814

Caecum glabrum (Montagu 1803)

Bittium reticulatum (da Costa 1778)

Turritella communis Risso 1826

Aporrhais pespelicani (Linnaeus 1758)

Trivia monacha (da Costa 1778)

Lunatia alderi (Forbes 1838)

Lunatia catena (da Costa 1778)

Order Heterogastropoda

Triphora adversa (Montagu 1803)

Epitonium clathrus (Linnaeus 1758)

Epitonium turtonis (Turton 1819)

Vitreolina philippii (Rayneval \& Ponzi 1854)

Order Neogastropoda
Nucella lapillus (Linnaeus 1758)

Buccinum undatum Linnaeus 1758

Neptunea antiqua (Linnaeus 1758)

Hinia incrassata (Ström 1768)

Hinia pygmaea (Lamarck 1822)

Hinia reticulata (Linnaeus 1758)

Cytharella coarctata (Forbes 1840)

Oenopota turricola (Montagu 1803)

Raphitoma linearis (Montagu 1803)

Subclass Heterobranchia

Order Heterostropha

Omalogyra atomus (Phillippi 1841)

Brachystomia eulimoides Hanley 1844

Odostomia scalaris MacGillivray 1843

Chrysallida indistincta (Montagu 1808)

Chrysallida obtusa (Brown 1827)

Chrysallida spiralis (Montagu 1803)

Ebala nitidissima (Montagu 1803)

Eulimella laevis (Brown 1827)

Odostomia conoidea Winckworth 1932

Odostomia turrita Hanley 1844

Odostomia albella Lovén 1846

Odostomia plicata (Montagu 1803)

Turbonilla lactea (Linnaeus 1758)

Subclass Opisthobranchia

Order Bullomorpha

Acteon tornatilis (Linnaeus 1758)

Cylichna cylindracea (Pennant 1777)

Philine aperta (Linnaeus 1767)

Philine punctata (Adams 1800)

Order Anaspidea

Diaphana minuta Brown 1827

Retusa obtusa (Montagu 1803)

Retusa truncatula (Bruguière 1792)

Retusa umbilicata (Montagu 1803)

Akera bullata Müller 1776

Class Bivalvia

Subclass Palaeotaxodonta

Order Nuculoida

Nucula nitidosa Winckworth 1930

Nucula nucleus (Linnaeus 1767)

Subclass Pteriomorpha

Order Mytiloida

Mytilus edulis Linnaeus 1758

Modiolula phaseolina (Philippi 1844)

Modiolus adriaticus (Lamarck 1819)

Modiolus modiolus (Linnaeus 1758)

Musculus discors (Linnaeus 1767)

Modiolaria tumida (Hanley 1843)

Order Pterioida

Aequipecten opercularis (Linnaeus 1758) 
Chlamys varia (Linnaeus 1758)

Pecten maximus (Linnaeus 1758)

Pododesmus patelliformis (Linnaeus 1761)

Anomia ephippium Linnaeus 1758

Heteranomia squamula (Linnaeus 1758)

Ostrea edulis Linnaeus 1758

Subclass Heterodonta

Order Veneroida

Lucinoma borealis (Linnaeus 1758)

Thyasira flexuosa (Montagu 1803)

Mysella bidentata (Montagu 1803)

Tellimya ferruginosa (Montagu 1803)

Turtonia minuta (Fabricius 1780)

Lepton nitidum (Turton 1822)

Kellia suborbicularis (Montagu 1803)

Acanthocardia echinata (Linnaeus 1758)

Parvicardium exiguum (Gmelin 1791)

Parvicardium ovale (Sowerby 1840)

Parvicardium scabrum (Philippi 1844)

Cerastoderma edule (Linnaeus 1758)

Laevicardium crassum (Gmelin 1791)

Mactra stultorum (Linnaeus 1758)

Lutraria lutraria (Linnaeus 1758)

Spisula elliptica (Brown 1827)

Spisula solida (Linnaeus 1758)

Spisula subtruncata (da Costa 1778)

Ensis ensis (Linnaeus 1758)

Phaxas pellucidus (Pennant 1777)

Angulus tenuis (da Costa 1778)

Fabulina fabula (Gmelin 1791)

Macoma balthica (Linnaeus 1758)

Macoma calcarea (Gmelin 1791)

Donax vittatus (da Costa 1778)

Gari depressa (Pennant 1777)

Gari fervensis (Gmelin 1791)

Scrobicularia plana (da Costa 1778)

Abra alba (Wood 1802)

Abra nitida (Müller 1776)

Abra prismatica (Montagu 1803)

Arctica islandica (Linnaeus 1767)

Chamelea striatula (da Costa 1778)

Clausinella fasciata (da Costa 1778)

Paphia aurea (Gmelin 1791)

Tapes decussatus (Linnaeus 1758)

Timoclea ovata (Pennant 1777)

Venerupis rhomboides (Pennant 1777)

Venerupis pullastra (Montagu 1803)

Dosinia exoleta (Linnaeus 1758)

Dosinia lincta (Montagu 1803)

Mysia undata (Pennant 1777)

Order Myoida
Mya arenaria Linnaeus 1758

Mya truncata Linnaeus 1758

Corbula gibba (Olivi 1792)

Hiatella arctica (Linnaeus 1758)

Hiatella rugosa (Linnaeus 1758)

Saxicavella jeffreysi Winckworth 1930

Barnea candida (Linnaeus 1758)

Pholas dactylus Linnaeus 1758

Zirfaea crispata (Linnaeus 1758)

Subclass Anomalodesmata

Order Pholadomyoida

Thracia phaseolina (Lamarck 1818)

Total for Holocene Vendsyssel: 133 (53.8\%)

\section{The Skagen Well area}

The hitherto recorded molluscan assemblages from Danish deposits of Late Quaternary age are littoral to sublittoral - mostly - especially from the Holocene. The new information from the Skagen Well containing deeper-water deposits is presented below.

Subfossil Holocene species in the Skagen Well

Class Gastropoda

Subclass Prosobranchia

Order Neotaenioglossa

Lacuna pallidula (da Costa 1778)

Hydrobia ulvae (Pennant 1777)

Barleeia unifasciata (Montagu 1803)

Onoba vitrea (Montagu 1803)

Rissoa albella Lovén 1846

Rissoa violacea Desmarest 1814

Bittium reticulatum (da Costa 1778)

Turritella communis Risso 1826

Aporrhais pespelicani (Linnaeus 1758)

Lunatia alderi (Forbes 1838)

Lunatia montagui (Forbes 1838)

Order Heterogastropoda

Epitonium trevelyanum (Johnston 1841)

Aclis minor (Brown 1827)

Polygireulima sinuosa (Sacco 1836)

Vitreolina collensi (Sykes 1903)

Vitreolina philippii (Rayneval \& Ponzi 1854)

Graphis albida (Kanmacher 1798)

Melanella lubrica (Monterosato 1891)

Melanella alba (da Costa 1778)

Hemiaclis ventrosa (Jeffreys MS Fricle 1874)

Order Neogastropoda

Buccinum undatum Linnaeus 1758 
Hinia pygmaea (Lamarck 1822)

Hinia reticulata (Linnaeus 1758)

Oenopota turricola (Montagu 1803)

Mangelia brachystoma (Philippi 1844)

Subclass Heterobranchia

Order Heterostropha

Chrysallida decussata (Montagu 1803)

Eulimella scillae (Scacchi 1835)

Odostomia conoidea Winckworth 1932

Odostomia umbilicaris (Malm 1863)

Turbonilla delicata (Monterosato 1874)

Turbonilla sinuosa (Jeffreys 1884)

Subclass Opisthobranchia

Order Bullomorpha

Cylichna alba (Brown 1827)

Order Anaspidea

Retusa truncatula (Bruguière 1792)

Retusa umbilicata (Montagu 1803)

Class Bivalvia

Subclass Palaeotaxodonta

Order Nuculoida

Nucula nitidosa Winckworth 1930

Nucula nucleus (Linnaeus 1767)

Nuculana minuta (Müller 1776)

Subclass Pteriomorpha

Order Mytiloida

Mytilus edulis Linnaeus 1758

Musculus discors (Linnaeus 1767)

Order Pterioida

Chlamys varia (Linnaeus 1758)

Heteranomia squamula (Linnaeus 1758)

Ostrea edulis Linnaeus 1758

Subclass Heterodonta

Order Veneroida
Thyasira flexuosa (Montagu 1803)

Mysella bidentata (Montagu 1803)

Tellimya ferruginosa (Montagu 1803)

Turtonia minuta (Fabricius 1780)

Acanthocardia echinata (Linnaeus 1758)

Parvicardium minimum (Philippi 1836)

Mactra stultorum (Linnaeus 1758)

Spisula subtruncata (da Costa 1778)

Phaxas pellucidus (Pennant 1777)

Angulus tenuis (da Costa 1778)

Fabulina fabula (Gmelin 1791)

Tellina pygmaea (Lovén 1846)

Donax vittatus (da Costa 1778)

Gari fervensis (Gmelin 1791)

Abra alba (Wood 1802)

Abra nitida (Müller 1776)

Abra prismatica (Montagu 1803)

Arctica islandica (Linnaeus 1767)

Chamelea striatula (da Costa 1778)

Timoclea ovata (Pennant 1777)

Order Myoida

Mya arenaria Linnaeus 1758

Corbula gibba (Olivi 1792)

Hiatella arctica (Linnaeus 1758)

Saxicavella jeffreysi Winckworth 1930

Barnea candida (Linnaeus 1758)

Pholas dactylus Linnaeus 1758

Subclass Anomalodesmata

Order Pholadomyoida

Lyonsia norvegica (Gmelin 1791)

Cochlodesma praetenue (Pulteney 1799)

Thracia phaseolina (Lamarck 1818)

Total for Holocene Skagen Well: 71 (28.7\%) 